\section{Chapter}

[15]

\title{
Role of earthworm biodiversity in soil fertility and crop productivity improvement
}

\author{
Nitin Kamboj, Amrit Kumar, Vishal Kamboj, Aditi Bisht, \\ Neeraj Pandey and Manisha Bharti
}

Department of Zoology and Environmental Sciences, Gurukula Kangri (Deemed to be University), Haridwar 249404, Uttarakhand, India

\begin{abstract}
The earthworms are the biological indicator of the soil ecosystem as they indicate the health and fertility of the soil for proper cropping. In the soil for proper aeration, rich nutrient contents earthworms are very essential organisms. They enhance the nutrients contents, increase water holding capacity, and improve microbial activity in the soil. All over the world approximately 3627 species of earthworms are there. Earthworms are of two type's micrdrilli and megadrilli, in microdrilli group about 280 species, and the rest all are under megadrilli. Megadrilli group earthworms are soil living earthworms, they are grouped under three subgroups epigeic, endogeic, and anecic. Earthworms work for formers day- night without any labor charge and make the soil more nutritious and more aerated that helps in crop production. The major problem nowadays is to be recycled the organic waste into humus like products. For crop production enhancement organic manure is a better option instead of chemical fertilizer. Earthworms decompose the organic waste into organic manure. By the use of vermi techniques (use of earthworms and organic waste) in the presence of oxygen organic waste turns into manure. The diversity and number of the earthworms in the soil change the soil texture and improve nutrient contents.
\end{abstract}




\section{Introduction}

The burrowing habit of earthworms makes the soil more porous and creates a new way to proper aeration in the soil. Earthworms feed decaying organic waste and soil and excrete approximately 60 to $80 \%$ of their feed (Sinha et al., 2002). Their role in soil fertility is very crucial as they make soil more air convener and discharge nutrients into the soil present in their feces. Earthworms are the "intestine of the earth" said by Aristotle they decompose the organic matter like plants leafs decaying fruits and soil also (Bhadauria and Sexana, 2010). The soil fertility increases with an increase in the nutrients, proper aeration, and water holding capacity, along with these factors microbial activities also have a huge impact on the soil. The fertility of the soil is directly proportional to the crop improvement (Rochester $e t$ al., 2001). Earthworms are delivering natural services to human beings from ancient times to nowadays by providing worm manure (vermicast) and vermiwash which positively affects soil fertility and crop improvement. Earthworms are the friends of the farmer they plough the field without any cost. Earthworms work for farmer's day-night and improve crop productivity by making their field more nutritive by converting the decaying organic matter into humus-like products. Earthworms are soil ecosystem modifiers as they are improving the soil nutrient profiles (Jones et al., 1994).

\section{General description and origin of earthworms}

Earthworms are soil worms that live in organic matter-rich soil. Earthworm feeds on surface decaying organic matter like plant leaf, fruit wastes, and other biodegradable wastes. They consume waste and convert it into humus-like products like vermicompost (manure). The ancestor of today's earthworms was originated approximately 600 million years ago and from the days of origin, they enhance the soil profile by making the soil more porous and secreting their mucus into the soil (Sinha, 2009). The first earthworm named by Linnaeus in 1758 that was Lumbricus terrestris. The next species of earthworm discovered was Eisenia fetida described by Savigny (1826) and Cuvier (1824). Earthworms are found over the globe except in snowy and very hot regions because earthworms are very temperature sensitive however they have diverse habitats where nutrient-rich organic matter easily available like the garden, paddy fields, and places rich in moisture contents nearly 55 to 60\% (Gupta et al., 2016). The earthworms is long, with cylindrical elongated body, compressed at both the ends, the body of earthworms is covered with a soft thin pellicle. The pellicles of earthworms are transparent and temperature-sensitive.

Body divided metamerically into 80 to 100 segments. Earthworms are hermaphrodite mean male and female reproductive organs found in single organisms. Sexual maturity attains at the age of 6 weeks. When environmental conditions favorable a pair of earthworms can produce more than 100 cocoons in 6 weeks to 6 months (Ismail, 1997).

Systematics: Earthworms come under the phylum Annelida and belong to the group Oligochaeta. The 


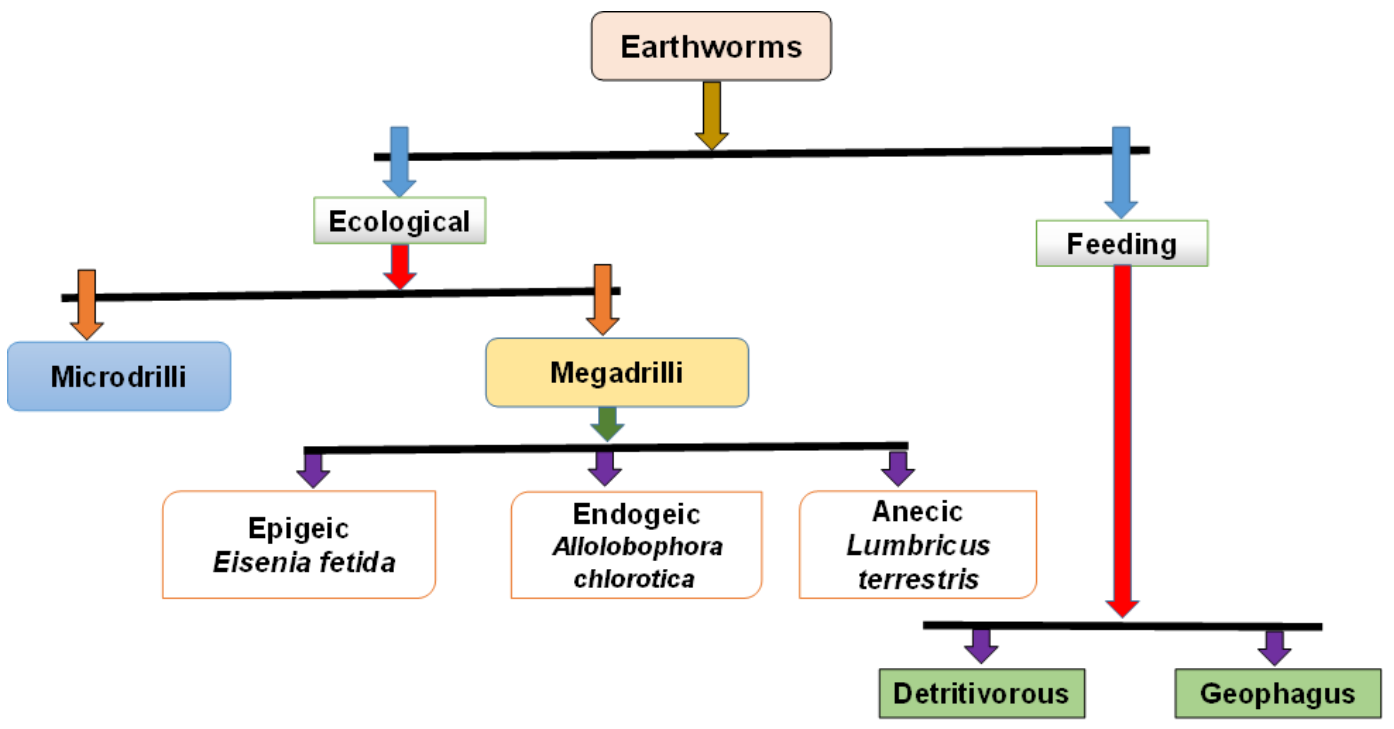

Figure 1. Systematic of earthworm distribution based on the ecological and feeding niche.

name earthworm is derived from the burrowing habit in the soil. In the world 3627 species of earthworm are present (Figure 1). Out of 3627 species, in India, 509 species are present which come under the 67 genera (Sinha et al., 2002).

\section{Classification of earthworms based on their ecological adaptations}

Based on the ecological adaptations firstly divided into two categories microdrilli and megadrilli. Out of total 3627 earthworm species, 280 are microdrilli, these are the aquatic species and the rest comes under species megadrilli. Further megadrilli can be classified into three subgroups depending on the inhabiting layer of the soil (Bouche, 1977) (Figure 2).

Epigeic earthworms (e.g. Eisenia fetida, Eudrilus eugeniae, Perionyx excavatus etc.): Epigeic earthworms are surface feeder detritivorous worms that feed on surface debris, decaying organic wastes like crop residues, decaying organic wastes, leaf litters, plant roots, and animal dung and convert them into vermicast. Due to the short lifespan fecundity rate is high and epigeic earthworms are reproduced in diverse habitat and harsh environments (Kozenko et al., 2020). E. fetida is the most suitable species for vermiculture over the globe. Epigeic earthworms are small in size, they are 1 to $18 \mathrm{~cm}$ in length (Xiao et al., 2011). Epigeic earthworms live in the upper soil layer and do not build burrows and as well as epigeic species of earthworms are not involved in organic and inorganic matter mixing. Feed decaying organic wastes. 


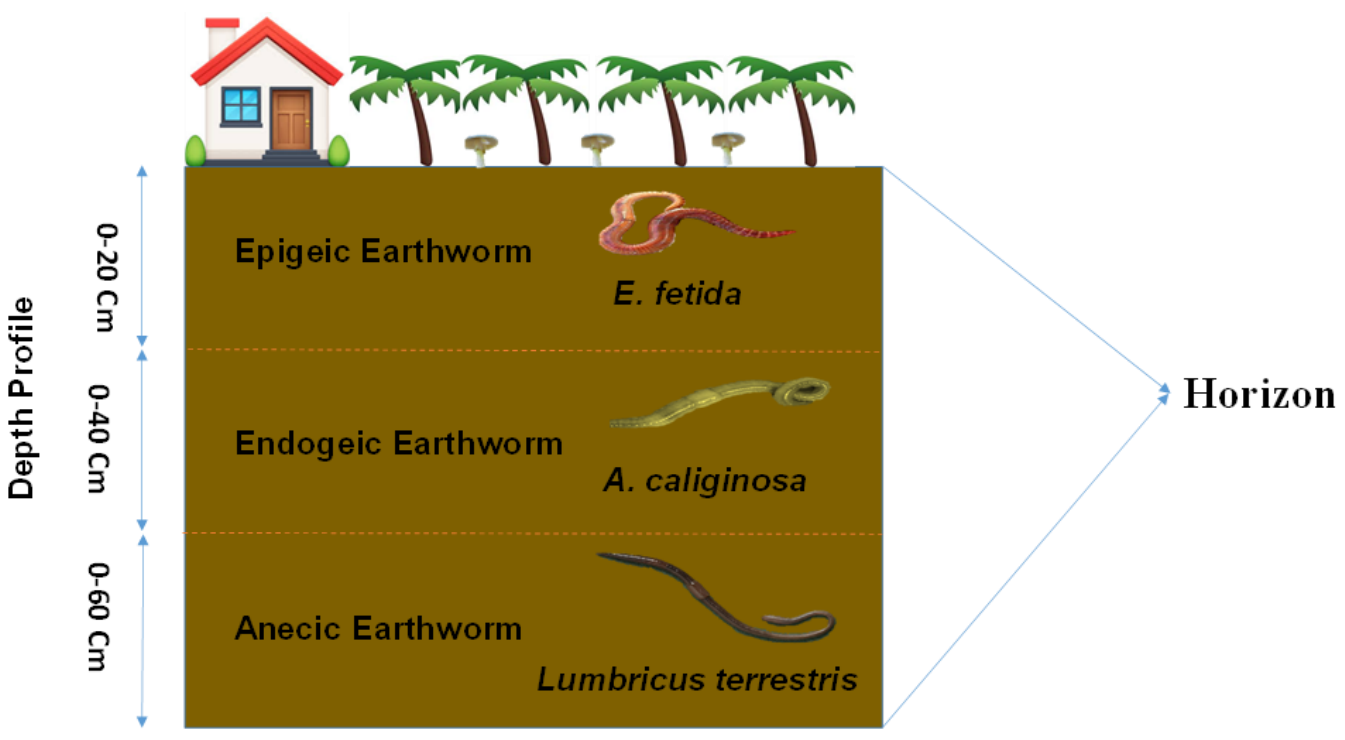

Figure 2. Habitat niche of the earthworms in the different layers of soil.

Endogeic species (e.g. Allolobophora chlorotica, Apporectodea icterica, Murchieona muldali, Octolasion cyaneum and Octolasion lacteum): Endogeic species of Earthworms are soil-inhabiting organisms they are not surface dwellers, live beneath the topsoil. The body size of the endogeic species is 2.5 to $30 \mathrm{~cm}$ in length. Endogeic species built horizontal burrow in the soil (Capoweiz et al., 2001; Perreault and Whalen, 2009). Endogeic species are the native species of Australian continents and are commonly found in New Zealand (Baker et al., 1999; Murchie and Gordon, 2013). The feeding matter of this species is soil which contains less organic matter as compared to surface layer feeding material. The soil texture is mainly changed by these species because endogeic earthworms feed more soil and less organic matter. These earthworms are not much suitable for vermicomposting but good for improving soil structure. The fecundity rate is low as compared to epigeic. Life span is relatively longer as compared to epigeic earthworms.

Anecic (e.g. Aporrectodea longa, Aporrectodea nocturna, Lumbricus friendi and Lumbricus terrestris): Anecic earthworms live in the deeper part of the soil in vertical burrows. They live in the soil at the depth of 3 meter. Anecic earthworms make vertical burrows and about $2 \mathrm{~cm}$ in diameter. They are the longest species category because anecic earthworm is about $3 \mathrm{~cm}$ up to $20 \mathrm{~cm}$ long. Anecic earthworms help in the mixing of the organic nutrients in the soil and enhance the soil texture (paedogenesis). Anecic earthworms come out from their burrows at night and move to soil surface and where they eat decaying organic organic matter with some part of soil. This species of earthworm is not suitable for vermiculture because of the low decomposition efficacy of organic matter, low fecundity but anecic earthworm have a longer life span as compared to epigeic and endogeic earthworms (Bhadauria and Sexana, 2010). 


\section{Classification of earthworms' based on the feeding behavior}

Based on the feeding habit earthworms can be classified as geophagous and detritivorous (Lee, 1985). Detritivorous feed on decaying organic waste like plant litters, decaying vegetables, fruits, and plant roots, cattle dungs at the soil surface and near the soil surface. They are humus former, convert the organic matter into the vermicompost. Epigeic is the detritivorous surface feeder of earthworms. Geophagus earthworm eat soil because they live beneath the soil in the horizontal burrow. Endogeic species are geophagus also called humus consumers because they eat soil with some part of organic waste.

\section{Earthworms as bioindicator of soil fertility and health}

The earthworms are the biological indicator of the soil ecosystem as they indicate the health and fertility of the soil for proper cropping (Pulleman et al., 2012). The number of earthworms in the soil determines the health of the soil and indicate the microorganisms like bacteria, fungi, viruses and other organisms in the soil, the high number of earthworm indicates the high biodiversity of the microorganisms in the soil (Lakzayi et al., 2015). A prominent microbial community is present in a rich organic matter area as many organisms like bacteria, fungi are present there for decomposition vermicompost is high in organic nutrients (Hedlund, 2002). Bacterial community and fungal hyphae in association with plant, enhance the soil productivity (Artursson et al., 2006; Nuccio et al., 2013). The high microbial population of bacteria, fungi, actinomycetes, and the higher enzymatic activity seen in the soil where the population of earthworm is high an area having higher earthworm diversity also have a higher microbial diversity that helps in the crop yield production without the use of chemical fertilizers (Haynes et al., 1999).

\section{Role of earthworms in crop improvement}

For a better and high yield of crop production and nutrients, rich organic production sustainable soil environment is necessary. Earthworms excrete various plant growth regulators in their mucus-like auxin and cytokinin (Krishnamoorthy and Vajranabhaiah, 1986). Earthworms play a key role in maintaining soil texture and balance soil ecosystem (Shuster et al., 2000). The major macrofauna of soil is earthworms they enhance the soil texture and nutrient content by secreting mucus in the soil, convert the organic biodegradable matter into nutrient-rich humus like manure (vermicast) (Sharma and Garg, 2018). Earthworms improve soil fertility by changing the biochemical and physical properties of soil. Earthworm excretion by-product vermicast is rich sources of various inorganic and organic nutrients (Edward et al., 1995; Kale, 1998; Lalitha et al., 2000). Vermicast increases the inorganic salt concentration which is used by the plant root system. Soyabean and wheat production increase $51 \%$ and $47 \%$ respectively by the use of earthworms and their vermicast (Palanisamy, 1996). Vermicomposting positively modulates the functioning of organic nutrients in the soil, mucus present in the vermicast 
speed up the primary breakdown of organic residue into the simpler compound which easily absorb by plants (Lavelle, 1988; Six et al., 1998; Kumar et al. 2019). Organic matter ingestion by earthworm from the soil, mixing them with gut mucus and convert them into humus (Jairajpuri, 1993). The feeding mechanism of earthworm function as a soil fertility enhancer because earthworms improve soil aeration, nutrient content and increase microbial activity (Hickman and Reid, 2008; Lemitiri et al., 2014; Medina et al., 2019). Earthworms burrowing and nutrient-rich mucus-secreting habit increase the soil profile by enhancing the physical, chemical, and microbial activity (Lin et al., 2016; Le Bayon et al., 2021). Organic matter in the gut contains a high level of nutrients and water as compared to nutrients and water present in the soil and these organic matters after digestion excrete out from the anus in the form of vermicast which is enriched with a high nutrient content that improves the soil ecosystem (Buck et al., 2000; Singh et al., 2016). In vermicast high nutrient content of N, P, K, and Ca is available which is easily absorbed by the plant root system and enhance the crop productivity (Bhadauria and Ramakrishnan, 1989).

\section{Technologies of vermicompost production}

Vermitechnology is a scientific method in which we use epigeic (surface feeder) and endogeic (subsurface feeder) species of earthworm for the conversion of biowaste into the vermicast with the help of soil microorganisms. Vermicomposting is the process of the decomposing of the biodegradable organic waste with the use of worms and microorganisms into the vermicast which is nutrient-rich organic manure. By the use of earthworms, we decompose organic biodegradable waste into the manure (Gunadi et al., 1997) and minimize the waste impact on mankind. In 21 st century rapid civilization, industrialization, and urbanization generate enormous waste from various sectors. In vermicomposting kitchen waste, institutional waste, paper waste, industrial waste, agricultural waste, and cow dung are used for earthworm feeding and earthworm convert these organic waste into manure. The role of earthworm in the formation of vermicompost from the biodegradable organic waste and improve fecundity of soil since 1881 by Darwin. The process of decomposition of waste into nutrient-rich manure was established by Kale et al. (1982) and Ismail (1993). Epigeic species of earthworms are extensively used in the vermicomposting like Eisenia fetida, Eudrilus eugeniae, Eisenia andrei, Perionyx excavatus, and Lumbricus rubellus are the most commonly used species in vermicomposting. Endogeic and anecic species of earthworms are not good for vermicomposting because both the species are not surface decaying material feeders, they live inside the soil by making horizontal and vertical burrow respectively but both the species are very useful in nutrient recycling and nutrient mixing in the soil. For this reason, endogeic and anecic species of earthworms are used for the modification of soil texture. Application of vermicompost on the agricultural practices we can minimize the negative impact of chemical fertilizers on the crops (Figure 3) . So by the use of vermicomposting we can easily decompose organic waste into nutrient rich organic manure. This technique convert the biodegradable waste into the humus like product without harming the environment (Tables 1 and 2). Compost obtain from the vermicomposting process is odorless, nutrient- 


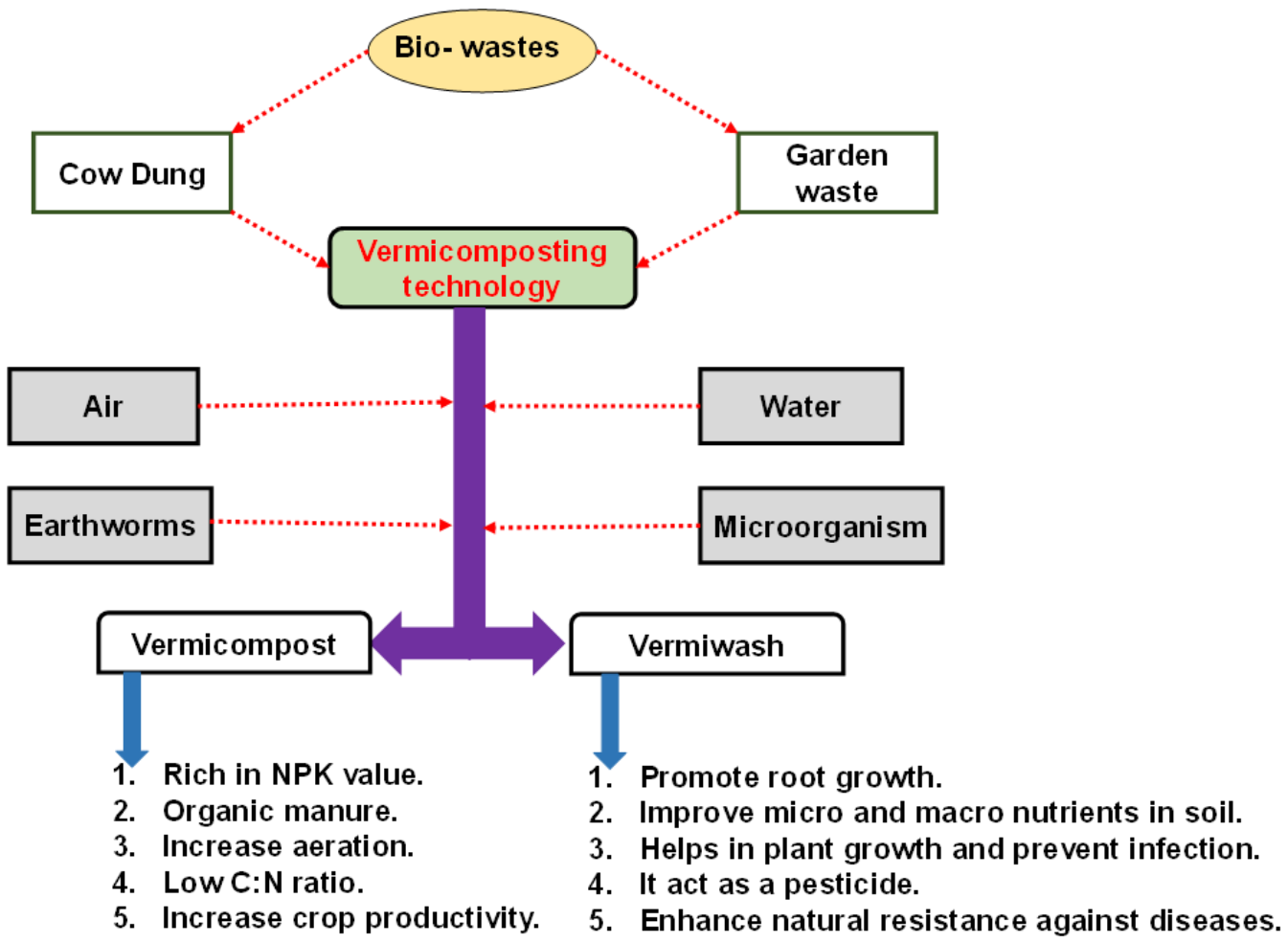

Figure 3. Vermicomposting process and use of vermicompost and vermiwash.

rich, and has many insecticidal properties (Rajiv et al., 2010; Sinha et al., 2011; 2013).

\section{Future scope and recommendation}

The future of vermitechnology in the field of agriculture is very bright as excessive use of pesticides and chemical soil productivity enhancer affect human health and soil health very badly. To overcome this problem whole world move toward organic farming. Vermicomposting is a very cheap and easier method to minimize this problem. By the use of earthworm minimize pesticide use in the crop field. To better understanding, the earthworm's role in agro ecosystems stabilization, improving soil texture, improve the microbial community in soil which helps in nitrogen fixation, and determine the factor that influences or inhibit the earthworm activity need more research. Earthworms are found all over the world except desert and snowy climate. Which species best suitable for organic waste decomposition and environment friendly and best adapted for their geographical climate. To understanding this problem needs more research in the field of earthworm biology. 
Table 1. Approximate physiochemical properties of vermicast (Perera and Nanthakumaran; 2015).

\begin{tabular}{llll}
\hline Properties & Vermicompost & Compost & Soil \\
\hline Organic matter & $17.77 \%$ & $76.90 \%$ & $20.72 \%$ \\
Nitrogen & $0.91 \%$ & $1.15 \%$ & $0.48 \%$ \\
Phosphorous & $0.14 \%$ & $0.17 \%$ & $0.11 \%$ \\
Potassium & $0.2 \%$ & $0.6 \%$ & $0.5 \%$ \\
Carbon & $9.90 \%$ & $44.35 \%$ & $11.95 \%$ \\
C/N ratio & $10.87 \%$ & 38.56 & 24.85 \\
pH & 6.98 & 7.21 & 7.25 \\
Electrical conductivity & 1.1 & 0.2 & 0.4 \\
Moisture contents & $15.58 \%$ & $12.20 \%$ & $11.64 \%$ \\
Bulk density & $0.5 \mathrm{~g} \mathrm{~cm}^{-3}$ & $1.3 \mathrm{~g} \mathrm{~cm}^{-3}$ & $1.6 \mathrm{~g} \mathrm{~cm}^{-3}$ \\
Particle density & $2.49 \mathrm{~g} \mathrm{~cm}^{-3}$ & $2.50 \mathrm{~g} \mathrm{~cm}^{-3}$ & $2.68 \mathrm{~g} \mathrm{~cm}^{-3}$ \\
porosity & 0.76 & 0.48 & 0.40 \\
\hline
\end{tabular}

Table 2. Studies on utilization of industrial wastes and organic amendments for vermicomposting.

\begin{tabular}{|c|c|c|c|}
\hline Industrial waste & Organic amendments & Earthworm species & References \\
\hline Paper mill waste & Primary sewage sludge & Eisenia andrei & Elvira et al. (1996) \\
\hline Paper mill waste & Cattle manure & Eisenia andrei & Elvira et al. (1998) \\
\hline Paper mill sludge & Cow dung & Eisenia fetida & Kaur et al. (2010) \\
\hline Food industry sludge & $\begin{array}{l}\text { Cow dung and Poultry } \\
\text { droppings. }\end{array}$ & Eisenia fetida & Banu et al. (2005) \\
\hline Solid textile mill sludge & Cow dung & Eisenia fetida & $\begin{array}{l}\text { Kaushik and Garg } \\
(2003)\end{array}$ \\
\hline Textile industry waste & Cow dung and soil & Eisenia fetida & Garg et al. $(2006 a, b)$ \\
\hline Sugar mill filter cake & Horse dung & Eisenia fetida & $\begin{array}{l}\text { Sangwan et al. } \\
\text { (2008) }\end{array}$ \\
\hline Olive oil industry waste & Municipal biosolids & Eisenia andrei & Benitez et al. (2005) \\
\hline Coffee pulp Pressmud & Cow dung & Perionyx ceqlanensis & $\begin{array}{l}\text { Prakash and } \\
\text { Karmegam (2010) }\end{array}$ \\
\hline Sugar industry sludge & $\begin{array}{l}\text { Cow dung, biogas slurry } \\
\text { and wheat straw }\end{array}$ & Eisenia fetida & Suthar (2010) \\
\hline $\begin{array}{l}\text { Sago industry solid } \\
\text { waste }\end{array}$ & $\begin{array}{l}\text { Cow dung and poultry } \\
\text { manure }\end{array}$ & Eisenia fetida & $\begin{array}{l}\text { Subramanian et al. } \\
\text { (2010) }\end{array}$ \\
\hline Distillery sludge & Cow dung & Eisenia fetida & Suthar (2008) \\
\hline Dairy industries sludge & Sewage sludge & Eisenia fetida & Gratelly et al. (1996) \\
\hline Solid paper mill waste & Brewery yeast & Lumbricus terrestris & Butt (1993) \\
\hline
\end{tabular}




\section{Conclusion}

Several studies conclude that the role of earthworm diversity to improve soil fertility and enhance crop productivity. Earthworms digest organic matter and convert them into the humus. Humus has a high value of inorganic salts like $\mathrm{N}, \mathrm{P}, \mathrm{K}$, and $\mathrm{Ca}$ these are the main integrant that enhances the crop productivity. The earthworm found in the different layer of the soil like epigeic earthworm found in the upper layer of the soil and not built the permanent burrow so this species is not involved in the mixing nutrients and aeration in the soil but the composting process is very fast as it decomposes biodegradable organic matter into the nutrient-rich manure. Vermicast or earthworm manure changes the soil profile, texture, and stabilization of the microbial community in the soil. Endogeic earthworms live in the horizontal burrow and feed on soil and some plant litter and help in the mixing of nutrients in the soil and change the texture of the soil. Anecic earthworms live in the deeper parts of the soil by making a vertical burrow. The decomposition efficiency of organic waste of anecic earthworms is very low but this species eat organic wastes like plants litters, leaves, decaying organic wastes on the soil surface. For feeding they come out their burrows at night and feed then returns to their burrows. They excrete their droppings in their burrows and changes texture, aeration, nutrient content in the soil. So the impact of the earthworm biodiversity on soil fertility and crop improvement is very important.

\section{Acknowledgments}

The author thanks the Department of Zoology and Environmental Science, Gurukula Kangri (Deemed to be University), Haridwar for providing the lab facility.

\section{References}

Artursson, V., Finlay, R.D. and Jansson, J.K. (2006). Interactions between arbuscular mycorrhizal fungi and bacteria and their potential for stimulating plant growth. Environmental Microbiology, 8(1): 1-10.

Baker, G.H., Carter, P.J. and Barrett, V.J. (1999). Survival and biomass of exotic earthworms, Aporrectodea spp. (Lumbricidae), when introduced to pastures in south-eastern Australia. Australian Journal of Agricultural Research, 50(7): 1233-1245.

Banu, J.R., Esakkiraj, S., Nagendran, R. and Logakanthi, S. (2005) Biomanagement of petrochemical sludge using an exotic earthworm Eudrilus eugeniae. Journal of Environmental Biology, 26: 43-47.

Benitez, E., Sainz, H. and Nogales, R. (2005) Hydrolytic enzyme activities of extracted humic substances during the vermicomposting of a lignocellulosic olive waste. Bioresource Technology, 96: 785-790.

Bhadauria, T. and Ramakrishnan, P.S. (1989). Earthworm population dynamics and contribution to nutrient cycling during cropping and fallow phases of shifting agriculture (Jhum) in north-east India. Journal of Applied Ecology, S1: 505-520.

Bhadauria, T. and Saxena, K.G. (2010). Role of earthworms in soil fertility maintenance through the production of biogenic structures. Applied and Environmental Soil Science, 1-10.

Buck, C., Langmaack, M. and Schrader, S. (2000). Influence of mulch and soil compaction on earthworm cast properties. Applied Soil Ecology, 14(3): 223-229.

Butt, K.R. (1993) Utilisation of solid paper-mill sludge and spent brewery yeast as feed for soil-dwelling earthworms. Bioresour Bioresource Technology, 44: 105-107. 
Capowiez, Y., Monestiez, P. and Belzunces, L. (2001). Burrow systems made by Aporrectodea nocturna and Allolobophora chlorotica in artificial cores: morphological differences and effects of interspecific interactions. Applied Soil Ecology, 16(2): 109120.

Cuvier, G. (1824). Analyse des travaux de l'Académie royale des sciences, pendant l'année 1824. imprimerie de Firmin Didot.

Darwin, C. (1892). The formation of vegetable mould through the action of worms: with observations on their habits, Vol. 37, pp. 123-202.

Edwards, C.A., Bohlen, P.J., Linden, D.R. and Subler, S. (1995). Earthworms in agroecosystems. In: Earthworm Ecology and Biogeography in North America. (Hendrix, P. F. eds.), Lewis Publisher, Boca Raton, FL, pp. 185-213.

Elvira, C., Goicoechea, M., Sampedro, L., Mato, S. and Nogales, R. (1996) Bioconversion of solid paper-pulp mill sludge by earthworms. Bioresource Technology, 75: 173-177.

Elvira, C., Sampedro, L., Benitez, E. and Nogales, R. (1998). Vermicomposting of sludges from paper mill and dairy industries with Eisenia andrei: a pilot-scale study. Bioresource Technology, 63(3): 205-211.

Garg, P., Gupta, A. and Satya, S. (2006a) Vermicomposting of different types of waste using Eisenia foetida: a comparative study. Bioresource Technology, 97: 391-395.

Garg, V.K., Kaushik, P. and Dilbaghi, N. (2006b) Vermiconversion of wastewater sludge from textile mill spiked with anaerobically digested biogas plant slurry employing Eisenia foetida. Ecotoxicology and Environmental Safety, 65(3): 412-419.

Gratelly, P., Benitez, E., Elvira, C., Polo, A. and Nogales, R. (1996) Stabilization of sludge from a dairy processing plant using vermicomposting. In: Rodriguez-Barrueco C (ed) Fertilizers and environment. Kluwer, The Netherlands, pp. 341-343.

Gunadi, B., Blount, C. and Edwards, C.A. (2002). The growth and fecundity of Eisenia fetida (Savigny) in cattle solids pre-composted for different periods. Pedobiologia, 46(1): 15-23.

Gupta, K.K., Aneja, K.R. and Rana, D. (2016). Current status of cow dung as a bioresource for sustainable development. Bioresources and Bioprocessing, 3(1): 1-11.

Haynes, R.J., Fraser, P.M., Tregutha, R.J., Piercy, J.E., Diaz-Cosin, D.J., Jesus, J.B., Trigo, D. and Garvin, M.H. (1999). Size and the activity of the microbial biomass and N, S, and P availability in earthworm casts derived from arable and pastoral soil amended with plant residues. 6th International Symposium on Earthworm Ecology. Vigo, Spain. Pedobiologia, pp. 43: $568-573$

Hedlund, K. (2002). Soil microbial community structure in relation to vegetation management on former agricultural land. Soil Biology and Biochemistry, 34(9): 1299-1307.

Hickman, Z.A. and Reid, B.J. (2008). Earthworm assisted bioremediation of organic contaminants. Environment International, 34(7): 1072-1081.

Ismail, A. (1997). Vermicology: the biology of earthworms. Orient Longman. pp. 23-40.

Ismail, S.A. (1993). Keynote papers and extended abstracts. In Congress on traditional sciences and technologies of India, IIT, Mumbai, Vol. 10, pp. 27-30.

Jairajpuri, M.S. (1993). Earthworms and vermiculture: an introduction. In: Earthworm resources and vermiculture, pp. 1-5.

Jones, C.G., Lawton, J.H. and Shachak, M. (1994). Organisms as ecosystem engineers. In Ecosystem management. Springer, New York, NY, pp. 130-147.

Kale, R.D., RD, K. and Bano, K. (1982). Potential of Perionyx excavatus for utilizing organic wastes. International Journal of Recycling of Organic Waste in Agriculture, 5: 65-86.

Kale, R.D. (1998). Earthworm Cinderella of Organic Farming. Prism Book Pvt Ltd, Bangalore, India. pp. 88 .

Kaur, A., Singh, J., Vig, A.P., Dhaliwal, S.S. and Rup, P.J. (2010). Cocomposting with and without Eisenia fetida for conversion of toxic paper mill sludge to a soil conditioner. Bioresource Technology, 101(21): 8192-8198.

Kaushik, P. and Garg, V.K. (2003) Vermicomposting of mixed solid textile mill sludge and cow dung with epigeic earthworm Eisenia foetida. Bioresource Technology, 90: 311-316.

Kozenko, K., Medvedev, A., Medvedeva, L., Zemlyanitsina, S. and Komarova, O. (2020). Vermicompost Production as a Means of Inclusive Green Economy Development in Rural Settlements. In IV International Scientific and Practical Conference'Anthropogenic Transformation of Geospace: Nature, Economy, Society'(ATG 2019) Atlantis Press. pp. 134-139.

Kumar, V., Kumar, P. and Singh, J. (2019). An introduction to contaminants in agriculture and environment. In: Contaminants 
in Agriculture and Environment: Health Risks and Remediation, 1: 1-8.

Krishnamoorthy, R.V. and Vajranabhaiah, S.N. (1986). Biological activity of earthworm casts an assessment of plant growth promotor levels in the casts. Proceedings: Animal Sciences, 95(3): 341-351.

Lakzayi, M., Moradi, H., Sabbagh, E. and Rigi, K. (2015). Effect of vermicomposting on microbial biomass in contaminated soil by heavy metals. Journal of Biodiversity and Environmental Sciences, 6(1): 85-101.

Lalitha, R., Fathima, K. and Ismail, S.A. (2000). Impact of biopesticides and microbial fertilizers on productivity and growth of Abelmoschus esculentus. Vasundhara. The Earth. 1\&2: 4-9.

Lavelle, P. (1988). Earthworm activities and the soil system. Biology and Fertility of Soils, 6(3): 237-251.

Le Bayon, R.C., Bullinger, G., Schomburg, A., Turberg, P., Brunner, P., Schlaepfer, R. and Guenat, C. (2021). Earthworms, plants, and soils. Hydrogeology, Chemical Weathering, and Soil Formation, 81-103.

Lee, K.E. (1985). Earthworms: their ecology and relationships with soils and land use. Academic Press Inc.

Lemtiri, A., Colinet, G., Alabi, T., Cluzeau, D., Zirbes, L., Haubruge, É. and Francis, F. (2014). Impacts of earthworms on soil components and dynamics. A review. Biotechnologie, Agronomie, Société et Environnement, S3:1-18.

Lin, Z., Zhen, Z., Wu, Z., Yang, J., Zhong, L., Hu, H. and Zhang, D. (2016). The impact on the soil microbial community and enzyme activity of two earthworm species during the bioremediation of pentachlorophenol-contaminated soils. Journal of Hazardous Materials, 301: 35-45.

MB, B. (1977). Strate gies lombriciennes. Soil Organisms as Components of Ecosystems. Ecological Bulletins.-Stockholm, Sweden, 122-132.

Medina-Sauza, R.M., Álvarez-Jiménez, M., Delhal, A., Reverchon, F., Blouin, M., Guerrero-Analco, J.A. and Barois, I. (2019). Earthworms building up soil microbiota, a review. Frontiers in Environmental Science, 7: 81-90.

Murchie, A.K. and Gordon, A.W. (2013). The impact of the 'New Zealand flatworm', Arthurdendyus triangulatus, on earthworm populations in the field. Biological Invasions, 15(3): 569-586.

Nuccio, E.E., Hodge, A., Pett-Ridge, J., Herman, D.J., Weber, P.K. and Firestone, M.K. (2013). An arbuscular mycorrhizal fungus significantly modifies the soil bacterial community and nitrogen cycling during litter decomposition. Environmental Microbiology, 15(6): 1870-1881.

Palaniswamy S. (1996). Earthworm and Plant Interactions. Paper presented in ICAR Training Program; Tamil Nadu Agricultural University, Coimbatore.

Perera, K.I.M. and Nanthakumaran, A. (2015). Technical feasibility and effectiveness of vermicomposting at the household level. Tropical Plant Research, 2(1): 51-57.

Perreault, J.M. and Whalen, J.K. (2006). Earthworm burrowing in laboratory microcosms as influenced by soil temperature and moisture. Pedobiologia, 50(5): 397-403.

Prakash, M. and Karmegam, N. (2010) Vermistabilization of pressmud using Perionyx ceylanensis Mich. Bioresource Technology, 101: 8464-8468.

Pulleman, M., Creamer, R., Hamer, U., Helder, J., Pelosi, C., Peres, G. and Rutgers, M. (2012). Soil biodiversity, biological indicators, and soil ecosystem services - an overview of European approaches. Current Opinion in Environmental Sustainability, 4(5): 529-538.

Rajiv K,S., Sunita, A., Krunal, C., Vinod, C. and Brijal Kiranbhai, S. (2010). Vermiculture technology: reviving the dreams of Sir Charles Darwin for scientific use of earthworms in sustainable development programs. Technology and Investment, 110 .

Rochester, I.J., Peoples, M.B., Hulugalle, N.R., Gault, R. and Constable, G.A. (2001). Using legumes to enhance nitrogen fertility and improve soil condition in cotton cropping systems. Field Crops Research, 70(1): 27-41.

Sangwan, P., Kaushik, C.P. and Garg, V.K. (2008) Feasibility of utilization of horse dung spiked filter cake in vermicomposters using exotic earthworm Eisenia foetida. Bioresource Technology, 99: 2442-2448.

Sharma, K. and Garg, V.K. (2018). Solid-state fermentation for vermicomposting: a step toward sustainable and healthy soil. In Current Developments in Biotechnology and Bioengineering, Elsevier. pp. 373-413.

Shuster, W.D., Subler, S. and McCoy, E.L. (2000). Foraging by deep-burrowing earthworms degrades the surface soil structure of a fluventic Hapludoll in Ohio. Soil and Tillage Research, 54(3-4): 179-189. 
Singh, S., Singh, J. and Vig, A.P. (2016). Earthworm as ecological engineers to change the Physico-chemical properties of soil: soil vs vermicast. Ecological Engineering, 90: 1-5.

Sinha, R.K. (2009). Earthworms: the miracle of nature (Charles Darwin's 'unheralded soldiers of mankind \& farmer's friends').

Sinha, R.K., Hahn, G., Singh, P.K., Suhane, R.K. and Anthonyreddy, A. (2011). Organic farming by vermiculture: Producing safe, nutritive, and protective foods by earthworms (Charles Darwin's Friends of Farmers). Journal of Experimental Agriculture International, S1: 363-399.

Sinha, R.K., Herat, S., Agarwal, S., Asadi, R. and Carretero, E. (2002). Vermiculture and waste management: the study of the action of earthworms Eisenia foetida, Eudrilus euginae, and Perionyx excavatus on biodegradation of some community wastes in India and Australia. Environmentalist, 22(3): 261-268.

Sinha, R.K., Soni, B.K., Agarwal, S., Shankar, B. and Hahn, G. (2013). Vermiculture for organic horticulture: Producing chemical-free, nutritive \& health-protective foods by earthworms. Agricultural Science, 1(1): 17-44.

Six, J., Elliott, E.T., Paustian, K. and Doran, J. W. (1998). Aggregation and soil organic matter accumulation in cultivated and native grassland soils. Soil Science Society of America Journal, 62(5): 1367-1377.

Subramanian, S., Sivarajan, M. and Saravanapriya, S. (2010) Chemical changes during vermicomposting of sago industry solid wastes. Journal of Hazardous Materials, 179: 318-322.

Suthar, S. (2010) Pilot-scale vermireactors for sewage sludge stabilization and metal remediation process: comparison with small-scale vermireactors. Ecological Engineering, 36: 703-712.

Xiao, N., Ge, F. and Edwards, C.A. (2011). The regeneration capacity of an earthworm, Eisenia fetida, in relation to the site of amputation along the body. Acta Ecologica Sinica, 31(4): 197-204.

$* * * * *$

Cite this chapter as: Kumar, A., Kamboj, N., Kamboj, V., Bisht, A., Pandey, N. and Bharti, M. (2021). Role of earthworm biodiversity in soil fertility and crop productivity improvement. In: Biological Diversity: Current Status and Conservation Policies, Volume 1, Eds. Kumar., V., Kumar, S., Kamboj, N., Payum, T., Kumar, P. and Kumari, S. pp. 230-241, https:// doi.org/10.26832/aesa2021-bdcp-015 